\title{
El retrato de Rubén Darío por Tomás J. Leal da Câmara. Una amistad lusoamericana apenas recordada
}

\author{
Juan Manuel GONZÁLEZ MARTEL
}

\begin{abstract}
RESUMEN
El dibujante portugués Leal da Câmara (1876-1948) coincide en la capital española, en 1899, con Rubén Darío. Presentado al poeta, que por entonces era corresponsal de La Nación de Buenos Aires, inician un amistoso trato que continuará en París. Leal da Câmara hará en 1902 un óleo del vate nicaragüense en el límite entre el retrato y la caricatura.
\end{abstract}

Palabras clave: Modernismo, retrato, caricatura.

Rubén Darío's Portrait by Tomás J. Leal da Câmara. Luso-American Friendship just Remembered

\begin{abstract}
The Portuguese cartoonist Leal da Câmara (1876-1948) coincides in the Spanish capital in 1899, with Rubén Darío. Presented to the poet, who was then a correspondent for La Nación of Buenos Aires, start a friendly deal that will continue in Paris. Leal da Câmara in 1902 made a painting of the Nicaraguan poet the boundary between portraiture and caricature.

Keywords: Modernism, portrait, caricature.

SUMARIO: 1. Con la mano sobre el hombro de Darío. 2. Rubén, "estava invisível por ter passado a noite a ouvir um poema de Villaespesa"... 3. "La caricatura" de Rubén Darío en 1899. "Sus deformaciones recuerdan las imágenes de los espejos cóncavos y convexos". 4. En la revista "Vida y Arte", 1900. 5. En París "L'Assiette au beurre". "Cosas de España" y de Portugal, interpretadas por Leal y Sancha. 6. El retrato de Darío por Leal da Câmara en 1902. 7. 1912, en Lisboa con Darío. ¡Adiós, Maestro!, en el embarque de Rubén a América. 8. Bibliografía.
\end{abstract}

\section{A Consuelo Triviño, novelista colombiana que ama a Portugal.}

Tomás J. Leal da Câmara (1876-1948) -dibujante, caricaturista, cartelista, pintor, diseñador de interiores y de mobiliario- de nacionalidad portuguesa, estuvo autoexiliado en España entre 1898 y 1900. En su anecdotario destaca el haber sido uno de los protagonistas, durante esa estancia madrileña, de la disputa de los escritores Ramón del Valle-Inclán y Manuel Bueno, con el perjuicio de la manquedad 
del primero. Madrid y París serán las capitales en las que el artista luso residirá más tiempo durante su larga permanencia fuera de Portugal.

No fueron muchas las amistades portuguesas y brasileñas de Rubén Darío, a pesar de que siempre demostró interés por ambos países y, desde 1896, como crítico literario, destacó su atención por el ámbito cultural luso eligiendo al poeta Eugenio de Castro para cerrar las diecinueve semblanzas de escritores que componen Los raros, y, pasado el tiempo, persistió en tal curiosidad que cierra con su "Graça Aranha" en el Mundial de julio de 1913.

Por tal circunstancia, habría que tenerse en cuenta el temprano trato de Darío con el joven portugués Leal da Câmara, a partir de la estancia del poeta nicaragüense en Madrid, en su segundo viaje a Europa, en 1899.

Tomás, nacido en Panjim (Nova Goa, India), de padres portugueses, y residente desde niño en Lisboa, llegó por vez primera a Madrid, autoexiliado, con veintiún años. Fue un urgente viaje debido a la amenaza de destierro por delito de imprenta, por sus caricaturas antigubernamentales y en contra de la monarquía en publicaciones portuguesas como D. Quixote, Os Ridiculos, A Marselheza y A Corja. El dibujante, urgido por ese inminente riesgo de detención, desembarcó en Madrid trayendo consigo únicamente lo puesto y su repleto cartapacio de dibujos. Pero Leal da Câmara, gracias a su carácter abierto y a la evidente calidad de lo que mostraba de su trabajo, fue relacionándose con gente de las letras, del arte y del periodismo -entre ellos, Ramón del Valle-Inclán o Camilo Bargiela- que le manifestaron una abierta simpatía por su país, porque admiraban la cultura portuguesa y porque tenían ciertos conocimientos de las gentes y tierras lusas.

Rubén, por segunda vez en España, tras desembarcar en Barcelona el 8 de diciembre de 1898, ya estará en Madrid a comienzos de 1900, ocupándose de la corresponsalía de La Nación. Y pronto, además de sus crónicas semanales para América, empezó a colaborar en publicaciones madrileñas como La Vida Literaria, El Álbum de Madrid o Madrid Cómico, en cuyas redacciones coincidió con Leal da Câmara. El poeta y el dibujante empezaron a tratarse cordialmente, encontrándose con frecuencia en los cafés de la Puerta del Sol, en particular en el salón del Café de La Montaña.

\section{Con la mano sobre el hombro de Darío}

El testimonio escrito de tal amistad, una valoración de la valoración de la etapa primera de la obra de Leal da Câmara por parte de Darío, es temprano, y quizás es esta mención crítica en crónica enviada a la prensa de Buenos Aires, la primera que sobre del dibujante luso, como caricaturista, se publicó fuera de Portugal y, al tiempo, de las primeras, junto a las de Camilo Bargiela y Tomás C. Durán, que en España se ocupaban de Leal da Câmara en esa etapa de 1898 a 1900.

Y como prueba gráfica, sus presencias en las fotografías hechas en la comida de homenaje a Enrique Gómez Carrillo. Se la ofrecía La Vida Literaria, cuya dirección convocaba a los amigos del cronista en el restaurante Niza de La Bombilla. El guatemalteco, residente en París, donde era cónsul de su país, pasaba unos días en 
Madrid para publicitar su novela Del amor, del dolor y del vicio. Este joven escritor empezaba a colaborar decididamente en revistas literarias y periódicos españoles.

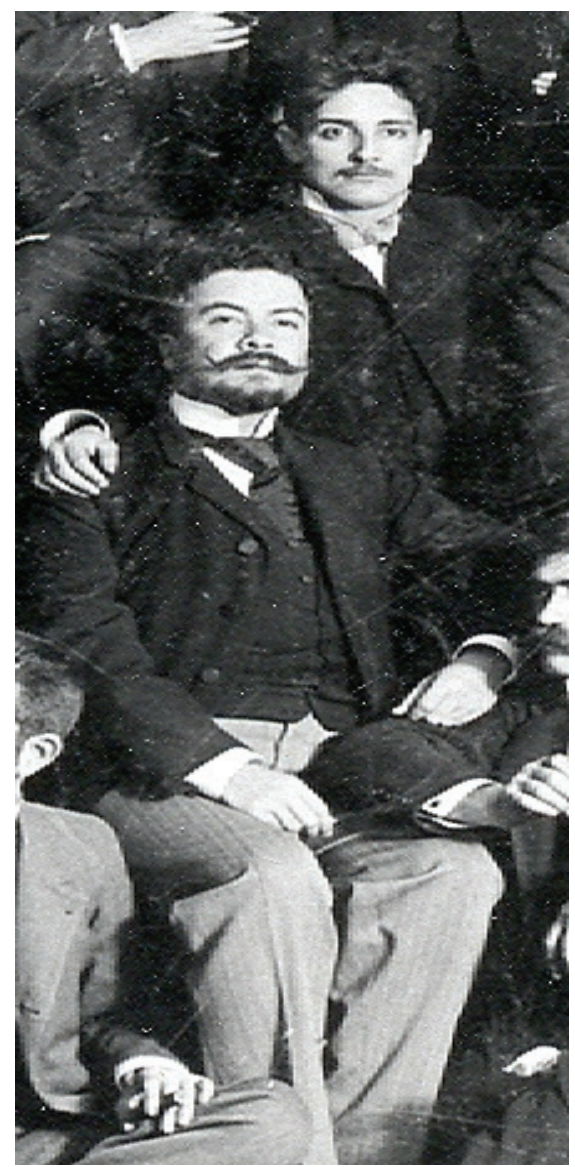

En el homenaje a E. Gómez Carrillo, Madrid, 1899.

Rubén Darío y, detrás, Leal da Câmara (Fondo Alejandro Sawa).

Rubén Darío, amigo de Gómez Carrillo desde 1889, había vuelto a encontrarse con algunas de sus amistades españolas de su primera estancia en Madrid en 1892, y ahora las nuevas presentaciones le estaban procurando más compañeros, sobre todo entre la promoción joven; y entre éstos, un veinteañero caricaturista portugués, autoexiliado por motivos políticos, con quien pronto simpatiza.

En abril, en efecto, habrían de aparecer retratados juntos en La Vida Literaria ${ }^{1}$, en una de las fotografías ${ }^{2}$ tomadas al grupo de comensales en dicha comida homenaje.

\footnotetext{
${ }^{1}$ La Vida Literaria, $\mathrm{n}^{\circ}$ 7, Madrid, 18.02.1899, pp. 118-119.
} 
Habían acudido, invitados por el propio cronista o por La Vida Literaria, conocidos y colaboradores de la revista. Alejandro Sawa y Rubén Darío ocuparon los puestos principales. En el momento de las fotografías, en torno a Darío y Sawa, sentados en sillas centrales, posaron los presentes. Leal da Câmara, con chaqueta y corbata de lazo, ijovencísimo aspecto y simpática sonrisa!, de pie, colocado inmediatamente detrás de Rubén y Alejandro, tiene colocada su mano derecha en el hombro del poeta americano.

\section{Rubén, "estava invisível por ter passado a noite a ouvir um poema de Villaespesa"...}

Otra noticia de este trato nos sitúa en el 15 de septiembre de este 1899. Comenta Leal da Câmara en carta familiar que "un jornal italiano reprodujo una caricatura mía. Díjomelo Rubén Darío, el cual me lo arranjará”’”.

Detalle que delata la cordial relación, la respetuosa admiración, del artista luso con el poeta americano, es la noticia del propio Leal da Câmara referida al nicaragüense en el suceso personal más ruidoso de su estancia en Madrid en 1899: el reto a duelo de Leal da Câmara, tras una discusión de trasfondo político, al joven aristócrata, periodista, López del Castillo. Leal da Câmara, ofendido por lo que consideró ofensas a Portugal por parte del literato español, lo desafía, situación que indirectamente, al poco, habría de tener dramáticas consecuencias en la persona de Valle Inclán.

En entrevista de 1945 de Leal da Câmara para la prensa portuguesa, entre los detalles de su evocación de la estancia en Madrid de 1898 a 1900, inevitablemente menciona aquel desafortunado suceso que le concernió: la manquedad de ValleInclán. Y en sus declaraciones, con cierta sorpresa para el conocedor de los detalles de aquella historia de desafíos y discutidos lances de honor, se nombra a Rubén Darío, convirtiendo al nicaragüense en otro personaje en torno a aquellas ofensas entre Leal da Câmara y López del Castillo.

$\mathrm{Al}$ recordar los días de aquel caso que "deu que falar em Madrid", confirma que el reproche de Valle-Inclán a Manuel Bueno durante la discusión del café de La Montaña, y que terminó con el bastonazo que hirió el brazo de don Ramón, fue por haber aceptado "ser testemunha do duelo", "Leal es un niño y ese duelo es un infanticidio, un crimen". Añade Tomás que, muy sorprendido a la mañana siguiente de su encontronazo en el paseo de Recoletos con López Castillo, tras leer la carta en la que se le urgía a concertar el duelo, acudió a hablar con Rubén. Sin duda, la edad y prestigio del poeta, y su misma condición de foráneo, movieron al portugués a recurrir a su consejo. Aun lejanísimas las circunstancias en ese 1945, Leal da Câmara afirma: "Procurei para tal o Rubén Darío que estava invisível por ter passado a noite a ouvir um poema de Villaespesa" (entrevista en el Diario de Lisboa, 1947), frase que es discreta deferencia para sólo aludir a una de las bien regadas veladas poéticas -las

${ }^{2}$ Leal da Câmara, "Homenaje a Enrique Gómez Carrillo". Orla, para fotografía de grupo. Firmada. 19'5x24., n’ 15, La Vida Literaria, 20.04.1899, pp. 248-249.

3 'me lo conseguirá'. Epistolario, n ${ }^{\circ} 380$. Casa-Museu Leal da Câmara. 
"tertulias" en casa del andaluz se prolongaban mucho...-, y, por consiguiente, una de las resacas del vate durante su temporada en Madrid. Así Rubén aparece también entre los dramatis personae de esta cuestión de honor de Leal da Câmara y, de rebote, de Valle-Inclán en el Madrid de 1899. Un incidente personal que, enmarcado como anécdota, habla de la difícil estancia, como exiliado político, del artista portugués en Madrid y del ambiente artístico y literario del Madrid finisecular.

En 1916, recordará José Francés sobre estos años:

Podemos, por lo tanto, fijar exactamente la fecha en que Leal da Câmara empezó a publicar sus dibujos en España. Y precisamente en La Vida Literaria que representaba entonces el periódico moderno, arbitrario, renovador de las viejas preceptivas estéticas, [...] Aún convulsa la patria por el desastre colonial, [...] Imaginaos que comenzaban a destacarse, junto a los hombres ya citados, los de Unamuno, Baroja, Martínez Ruiz, Valle-Inclán, Bueno, Rubén Darío, Villaespesa, Machado. [...] Poco más de veinte años tenía entonces el caricaturista portugués, [...] En Madrid, Leal da Câmara convivió con los artistas, con los escritores que habían de ser los futuros maestros.

\section{"La caricatura" de Rubén Darío en 1899. "Sus deformaciones recuerdan las imágenes de los espejos cóncavos y convexos"}

En "La cuestión de la revista. La caricatura", fechado el 24 de junio de 1899, se halla inserto un comentario de Darío sobre Leal da Câmara. Esta larga crónica estuvo destinada, primero, a los lectores bonaerenses de La Nación, y, luego, fue recogida en España contemporánea de $1901^{4}$.

En aquellos días del verano de 1899, Rubén mostró su crónica a Leal da Câmara antes de enviarla. Contenía un corto juicio sobre su obra gráfica, insertas en unas apreciaciones generales sobre las revistas españolas finiseculares y sus ilustradores. Y como la obra de Leal, a esta altura del año, aún no era muy abundante ni había celebrado exposición alguna, Darío se basa primordialmente en lo que del humorista portugués había visto en publicaciones periódicas madrileñas y en lo que Leal directamente le mostrase del contenido de su cartapacio, tanto algunos originales de su obra publicada en Lisboa como dibujos inéditos que había firmado en Madrid.

Darío, tras repasar la situación de las revistas en España, en comparación con las americanas y europeas, se pregunta cuál era la razón de que en España no prospere estas publicaciones, como en Inglaterra o Francia, achacándolo a la falta de cultura. Y de la caricatura, en estas publicaciones, observa que "tiene por campo una o dos páginas de cada "almacén" o revista ilustrada. Casi siempre la política y la actualidad es lo que forma el argumento", asegurando que "no existe hoy un caricaturista como el famoso [Francisco] Ortego ${ }^{5}$, por ejemplo. Como todo, la caricatura ha degenerado

${ }^{4}$ Obra reeditada en 1907 y 1917, en Mundo Latino, vol. 19.

${ }^{5}$ Algunos le llamaron el Gavarni español. Fueron muy conocidas las que presentaba en la revista Museo. 
también". Cita a Luque, Padró, Perea y Alaminos, como dibujantes de "caricatura política", así como a Mechachis, Cilla, Ángel Pons y Rojas.

Cuando valora la calidad media de éstos -"casi todos los actuales dibujantes, se proveen de inventiva y de rasgos felices en las revistas de otras naciones"-, su aprobación apenas se la concede a Apel.les Mestres ${ }^{6}$ y a Pellicer, y se limita a citar, entre los más jóvenes, a Moya, Sileno (Gedeón), Rojas, Sancha ("sobresale en la sátira política. Sancha se ha hecho un puesto especial; apoyado en el Fligene Blatter, y deformando, hace cosas que se imponen. Sus deformaciones recuerdan las imágenes de los espejos cóncavos y convexos; es un dibujo de abotargamientos o elefantiasis; monicacos macrocéfalos e hidrópicas marionetas."), Marín ("estudia mucho, y apoyado en Forain, hace excursiones al bello país de Inglaterra. Es un erudito de lo moderno, un simpático artista, cuyo modelo principal debe de ser una elegantísima y singular mujer, apasionada de D'Annunzio y fascinada por París") y Leal da Câmara ("portugués, joven, de indiscutible talento, dibuja en Madrid, un tanto desganado, con el pensamiento puesto en Jossot, a quien conoce, y animado por el espíritu de Cruikshank $^{7}$, a quien seguramente ignora.").

A Sancha y a Leal da Câmara, que gozaban de sus simpatías, por considerarlos aún en una etapa de formación y porque los trató en aquellos meses con mayor asiduidad, son los únicos de los que se atreve a precisar las influencias y admiraciones que observa en sus caricaturas. Efectivamente, son estos dos dibujantes, sumando el nombre de Marín, a pesar de las influencias que les atribuye, los favorecidos por la opinión de Darío. Al nombrar al portugués, por una parte, lo aprecia como artista "de indiscutible talento", elogio que comparte con Francisco Sancha y Ricardo Marín. Y por otra parte, ese "desganado" aplicado a Tomás Julio, parece indicar que ya por esas fechas el artista, al igual que Sancha, únicamente piensa en cómo marchar a París.

\section{En la revista Vida y Arte, 1900}

Desde que Gómez Carrillo tuvo la idea de fundar la revista Vida y Arte contó con la colaboración de Leal da Câmara como director artístico. Ya Leal había manifestado al cronista su intención de dar el salto a París y no dudamos de que el guatemalteco lo animase.

De las colaboraciones de Leal da Câmara en esta publicación modernista, la principal fue el diseño de la cubierta: friso de cabecera, sobre fondo de lazadas florales, rostro de semiperfil de mujer, con grandes ojos que miran frontalmente, peinada la abundante cabellera a dos bandós, sobre la que comienza la modernista caligrafía del nombre de la publicación. Y entre las varias viñetas, una al final del poema "Era un aire suave" de Rubén Darío, que aparece en la página cuarta, firmada

\footnotetext{
${ }^{6}$ Barcelona (1854-1936).

${ }^{7}$ George Cruikshank (1792-1878).
} 
con las iniciales de Leal: un negro corazón, en el centro, del que emanan unos efluvios, a modo de lacería de irregulares líneas paralelas ${ }^{8}$.

\title{
En París "L'Assiette au beurre". "Cosas de España" y de Portugal, interpretadas por Leal y Sancha.
}

En su primer tiempo parisiense, durante el final de 1900 y en 1901, Leal recupera el trato con Darío, quien se había instalado en el piso de Gómez Carrillo, del Fauburg Montparnasse.

En crónica del guatemalteco, desde París para El Liberal (Madrid). "Tres dibujantes ibéricos", del 29 de abril de 1901, Gómez Carrillo, tras una breve introducción, habla de Sancha, Solar de Alba y Leal da Câmara, "los artistas que en el mundo de los crayons cosmopolitas representan nuestra raza. Los tres son jóvenes". De Leal da Câmara comenta:

\begin{abstract}
A Leal da Câmara supongo que también le comparan sus amigos con los maestros más admirables, y especialmente con Caran d'Ache. El incienso, empero, no le nubla la vista. Cada uno de sus dibujos indica un progreso, por pequeño que sea, un progreso en la ejecución, en el métier, en lo acabado de la parte exterior, en fin. En su parte psicológica, la misma risa ruidosa y clownesca persiste, sin refinarse. Pero no persistirá mucho tiempo, no. Estudioso, modesto, apasionado de su arte llegará a reír menos y a sonreír más, y a sonreír mejor.
\end{abstract}

La previsión se cumplió. En su evolución, Leal da Câmara reconsidera sus retratos, aplicándoles una remozada factura, y ensayando con el color, con el empleo del óleo. Personaliza sus "psicologías", dentro de su persistente sencillez de rasgos, dando una mayor carnosidad a los volúmenes, agudizando lo que Camilo Bargiela había apuntado perspicaz párrafo de su crítica de mayo de $1900^{9}$ :

Si yo fuera hombre iracundo, como algunos suponen, me vengaba cruelmente del luso, dibujando su caricatura literaria, que a fe es fácil de hacer. Figuraos un cuervo con el pico torcido, y os formaréis la idea exacta de Leal da Câmara. Sí, ese es Leal: un cuervo que acude al olor de la carne... viva, para clavar el pico y buscar el alma de sus víctimas.

Las caricaturas personales que traza Leal da Câmara, no valen por el parecido que guardan con el original ni por la simplicidad elegante de la línea que de ambos caracteres participan; valen por la psicología estereotipada a punta de lápiz en los rasgos fisonómicos del caricaturizado. ¿Psicologías en caricatura?

8 Ídem, "Vida y Arte, una primera revista literaria de Gómez Carrillo para el mundo hispánico", Enrique Gómez Carrillo, cronista y director de publicaciones periódicas. Guatemala: Óscar de León Palacios, 2005, pp. 67-104.

${ }^{9}$ El Globo, Madrid, 18.05.1900. 
Eran meses de nuevas amistades y de idas a las redacciones ofreciendo su colaboración, de la primeras peticiones de las revistas ilustradas, la ocasión de las exposiciones en las galerías "Weil" o "Montmartre" o de los ocasionales encargos, algunos tan anecdóticos como el de la inesperada presentación que un amigo le hizo de un ruso que dirigía una volandera publicación revolucionaria, antizarista. Aquel conocido de la rue d'Assas, en habitación de un hotel frente al Petit Louxemburg, que le pidió una caricatura del zar, resultó ser Trotski. Y pronto, entre las sarcásticas caricaturas de Leal da Câmara, en su popular serie de postales, aparecerán tanto el zar como el káiser Guillermo $\mathrm{II}^{10}$.

Leal había empezado a colaborar en la revista satírica L'Assiette au beurre ${ }^{11}$. La firma de Leal da Câmara apareció muy pronto, coincidiendo con las de Jossot, Caran d'Ache, Grandjouan, D'Ostoya, Max Radiguet, Delannoy, Roubille, Ricardo Flores, Paul Iribe, Galanis, Hradecky, Édouard Bernard, Valloton, etc.

A Rubén Darío, tanto como amigo como por sus ideas y puesto diplomático, le llamaría la atención, al poco, la primera portada sobre la monarquía española en L'Assiette au beurre, en el número 70, del 2 de agosto, "Cosas de Espagne", en la que presentaban dibujos sus dos jóvenes amigos, Sancha y Leal. Un monográfico que firmaban Gosé, Sancha ${ }^{12}$, Câmara y Grandmontagne. A color, de medio cuerpo, de frente, el caricaturizado retrato de un joven Alfonso XIII con corona. Y además la caricatura del pretendiente carlista al trono, "Don Carlos", cuya leyenda reza: "-Au fait, à quoi prétend-il? Son neveu, mari de la princesse des Asturies, est l'héritier présomptif. Le jeu est fait! Rien ne va plus ! ». A la que se suman, las caricaturas del rostro -en blanco y negro, sobre fondo de color azul, y trazos en trama en rojo- de "Le petit père Sagasta": "-Le Mossieu Thiers de la future République espagnole", como contrapunto a la que presenta el retrato, con casco militar con penacho, del "Général Weyler", al que inmediatamente se le relacionaba con la represión en Cuba, "Un Monstre". Y como contraportada, un esperpéntico dibujo "feista" de Leal da Câmara: un gran frasco, con una forma humanoide monstruosa o un aborto en su interior, cuya tapa es una corona borbónica.

${ }^{10}$ De 8 de agosto, en el número 19 de L'Assiette au beurre aparece "Les Souverains", con comentario - "La seul chose qui m'embete, c'est d'etre leur college"- sobre el Káiser Guillermo II.

${ }^{11}$ Hebdomadaire, aparecido entre marzo de 1901 y octubre de 1912, de unas 16 páginas, con impresión en color. Exponente de la caricatura social y política, y de costumbres, de inicial tendencia anarquizante. Colaboraron más de 220 ilustradores y 73 autores comentaron los sucesivos números.

${ }^{12}$ Curiosamente, el dibujo titulado "Souvenir de la guerre cubaine", con la reina madre y el rey de España, es el primer dibujo antimonárquico que presenta Sancha en Francia. Aparece dos caricaturizados personajes, la Reina regente aconsejando a su hijo Alfonso, protegidos ambos por un muro, cual alto parapeto, hecho de sacas de dinero. La madre le dice: “-Quoi qu'il arrive, il faut assurer l'avenir ! Je vais vite envoyer tout ça dans une banque de New York". 


\section{El retrato de Darío por Leal da Câmara en 1902}

En 1901, Garnier Frères había publicado con el título España contemporánea una selección de trabajos periodísticos de Darío sobre sus impresiones españolas, presentados antes en La Nación de Buenos Aires. Y contenía la citada crónica "La cuestión de la revista. La caricatura", de 24 de junio de 1899.

Leal da Câmara releía, ahora en libro, con renovada curiosidad, este volumen con las crónicas en que Darío retrataba la España finisecular que él había conocido. Artículos con estampas -"Carnaval", "La joven literatura", "La España negra", "Semana Santa”, “¿Toros!”, "Una exposición”, "La fiesta de Velázquez”, "Libreros y editores", Los inmortales", "Una novela de Galdós", "El modernismo", "El cartel en España", "Jacinto Octavio Picón", etc.- que le recordarían muchas de sus mismas vivencias y a gente amiga.

Y mientras Darío opinó sobre la caricatura en 1899, en aquellos frecuentes encuentros entre amigos en los cafés de la Puerta del Sol, su propio rostro, su pausado gesto, tuvo que haber sido uno de los objetivos para un lápiz tan agudo como el de Leal da Câmara. ¡Esa rotunda figura de aire indoamericano!, que, por otra parte, tantas tentaciones descriptivas habrían de despertar entre escritores.

Lejos estaba la publicación en España de la que sería la caricaturización literaria más mencionada, y de las que, de haberla conocido el poeta, menos gracia le hubieran hecho al poeta: la incluida por Ramón del Valle-Inclán, en 1920, en Luces de bohemia, la puesta en boca del esperpéntico vejete de Hispalis, "Don Latino. -Allá está como un cerdo triste" o la repartida en las acotaciones de la escena novena de este esperpento:

Un café que prolongan empañados espejos. Mesas de mármol. Divanes rojos. [...] rincón donde está sentado y silencioso Rubén Darío. [...] Finalmente su máscara de ídolo se anima con una sonrisa cargada de humedad. [...] el gesto de ídolo evocador de terrores y misterios. [...] Rubén sale de su meditación con la tristeza vasta y enorme esculpida en os ídolos aztecas.

Se diría que cuando se plantea el retrato del poeta, al releer lo escrito por Darío sobre Sancha y sobre él en "La caricatura" de 1899, hubiese sopesado para la ejecución de su retrato del poeta algo de la estética que el crítico americano había juzgado como propia de los dibujos de Sancha -"Sus deformaciones recuerdan las imágenes de los espejos cóncavos y convexos; es un dibujo de abotargamientos o elefantiasis; monicacos macrocéfalos e hidrópicas marionetas"- y la influencias a lo Jossot y Cruikshanf ${ }^{13}$ que había señalado para él mismo. Pero, a la postre, sin recurrir a los extremos de dichos recursos, Leal da Câmara comprueba que con un somero

13 Véase J. M. González Martel, "La caricatura de Leal da Câmara ante la crítica modernista: Rubén Darío, Camilo Bargiela y Tomás C. Durán", Journal of Hispanic Modernisme, $\mathrm{n}^{\mathrm{o}}$ 1, 2010, pp. 67-84. 
acercamiento al amigo se captaba lo real de la encarnadura física que encerraba la sensibilidad lírica más poderosa del mundo hispánico. Leal da Câmara se adelantaba a Valle-Inclán con un retrato que, en este caso, sí pudo haberlo visto el poeta centroamericano.

De 1902 es el retrato de Darío, por Leal da Câmara, que se conserva en la CasaMuseu del pintor en la localidad de Rinchôa, en Portugal. Una imagen de Rubén Darío escasamente divulgada -salvo en publicaciones recientes de la Câmara Municipal de Sintra-, debido tal vez a no haberse concedido importancia a la relación del nicaragüense con el artista luso o por el posible rechazo a lo que podría enjuiciarse como excesiva caracterización realista del aspecto físico del centroamericano.

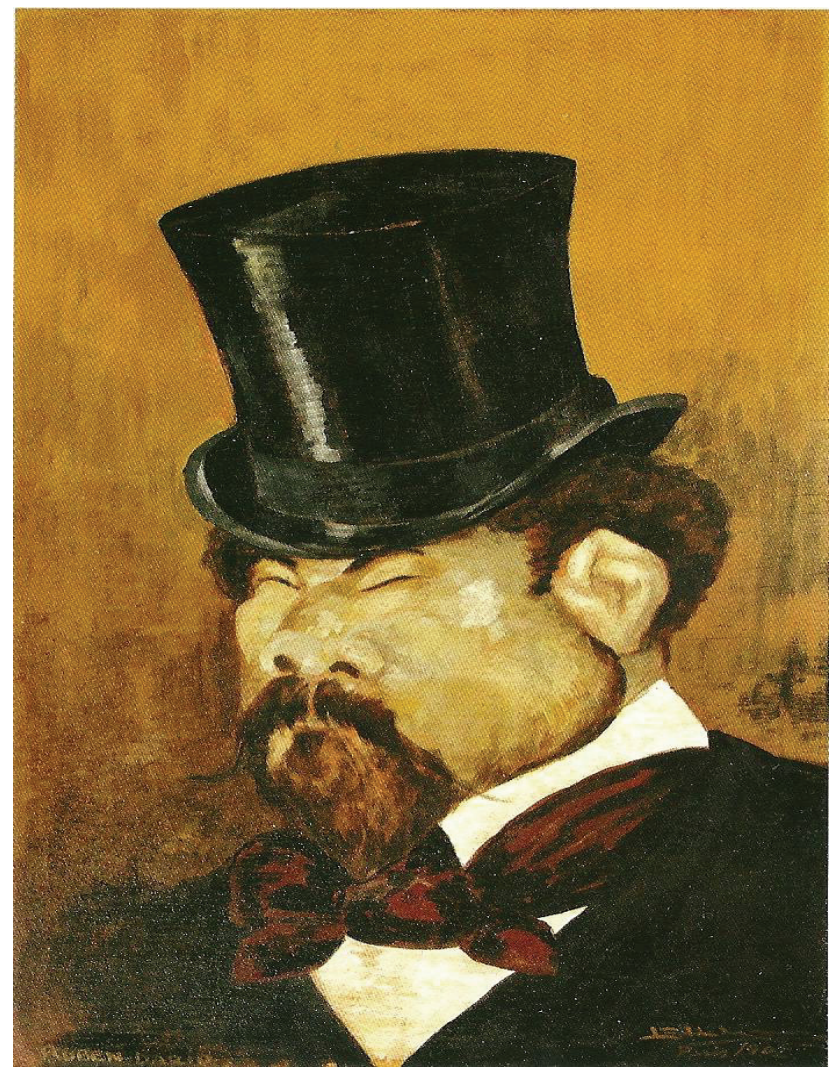

Un posible boceto de Rubén Darío, realizado en aquella anterior temporada madrileña de 1899 a 1900, pudo quedar entre los apuntes de Leal da Câmara y haber 
sido acicate para una nueva recreación al óleo, para una definitiva y desprejuiciada caricaturización del vate amigo, fiado en su seguridad estilística de ahora ${ }^{14}$.

Con un óleo, sobre contraplacado, de $41 \times 71 \mathrm{~cm}^{15}$, Tomás Júlio plasmó el busto de Darío, en semiperfil, con simplificado rasgo naturalista, componiendo un retrato al filo de la caricatura. Posiblemente el retrato, captado en su absoluta entidad mestiza, menos idealizado entre los hechos en vida al poeta. Firmado y fechado, en la parte inferior izquierda aparece el nombre "Rubén Darío".

Vestido con negra levita, Rubén luce anudada corbata de lazo de color burdeos sobre blanco cuello. Un reluciente sombrero de copa, objeto del atuendo convertido, como prolongación del rostro, en motivo central, cubre un cráneo de encrespado pelo castaño y cae sobre la frente hasta la línea de las cejas. Carnosas orejas y una achatada gran nariz, la cara de Darío, de prominente mandíbula con abultados mofletes, la define un bigote lacio y una escasa barba con tupido mentón a lo chivo. Y como si Leal da Câmara quisiese recluir en el interior del poeta toda la fuerza del misterio y el milagro de su sensibilidad y capacidad lírica, cierra casi por completo sus inclinados ojillos indianos.

\section{2, en Lisboa con Darío. ¡Adiós, Maestro!, en el embarque de Rubén a América}

El martes 3 de abril de 1912 se homenajeó en París "al maestro de la poesía castellana", que iba a emprender una gira por América, en compañía de Alfredo Guido, de Javier Bueno -"joven escritor redactor de Mundial y Elegancias"- y del fotógrafo Boyé. Una cena en el Café Riche a la que asistió "lo más selecto y lo más prestigioso de la intelectualismo hispano-americano residente en París". Según la reseña del Mundial del mes de mayo, Rubén Darío, con esos compañeros, marcharían "en breve a tierras de lengua española y a tierras de lengua portuguesa, en embajada de saludo cordial y demostración de agradecimiento, a cuantos acogieron favorablemente estas revistas hermanas".

En este 1912 Leal da Câmara, que había tenido muchas ocasiones de saludar en París a Darío, tendrá ocasión de saludar al maestro, en el comienzo de esta gira, en su propia Lisboa. Unos saludos de bienvenida a Portugal y, al poco, una afectuosa despedida resumirán lo que había sido la amistad del luso con el poeta nicaragüense. De ese reencuentro y del último adiós quedó constancia, escrita y gráfica, gracias a Javier Bueno, el reportero del periplo, en los cuadernos del 14 de junio y del 16, agosto, en "El viaje del Mundial", la crónica en que Bueno reseña, ilustrada con fotos de Boyé, del paso Rubén Darío y Alfredo Guido por la capital lisboeta.

No estaba ya Leal da Câmara en Francia cuando se empieza a publicar Mundial, en noviembre de 1911, ni cuando Darío en junio de 1912 emprende el viaje

14 En enero de 1901, gracias a su amistad con Francisco Sancha, que había empezado a colaborar en esta revista parisina, tenemos dibujos de Leal da Câmara en el periódico humorístico parisino Le Rire.

${ }^{15}$ Fue elegida, como pieza no 9, en el Catálogo de la Exposición en Lisboa en 1947. 
americano. Hacía poco que Tomás, apasionado republicano, había decidido regresar a Portugal, tras la proclamación de la República. ¡Muchas iniciativas por desarrollar a favor del nuevo Portugal! Entusiasmado por la caída de la monarquía y la instauración de un gobierno republicano en su patria, se olvida de París y, de golpe, lleno de proyectos, redobla su actividad artística en su país.

Se había notado la ausencia de Leal da Câmara en aquellas revistas ilustradas francesas y belgas que habían desplegado su carrera de artista gráfico. Como tampoco se interesa por que su nombre figurase entre los ilustradores que llegaron a colaborar en el Mundial, como Gosé, Simont, Lelong, Xaudaró, Orazi, Falgas, Castelluci, Vázquez Díaz, Parys, Basté, Syrovy, F. Viscal, etc.

Pero un día, Leal da Câmara, que había estado muy ocupado en las últimas semanas con el montaje de una exposición de su obra en Lisboa, se entera de que, por tren, llegaría Rubén Darío a Lisboa, a la estación del Rocío, y se alojaría en el vecino hotel Avenida Palace. El poeta, recibido por el embajador de Nicaragua, ya tenía programada al detalle la visita: conocer la ciudad, un detenido paseo por Sintra, y una recepción en la Legación de Nicaragua, en casa del Ministro Planas Suárez, a la que estuvieron invitados autoridades locales, parte del cuerpo diplomático acreditado en la capital, y algunas personalidades de las letras y la política. Y entre los encuentros particulares, la presentación del viejo escritor Antonio Alburquerque, que lo guía por rincones lisboetas; el saludo al joven dramaturgo Alfonso Gayo y el encuentro con Leal da Câmara, a quien Bueno, amigo suyo en París, le dedica un apartado en su reseña del viaje:

Una de las personalidades más salientes y más simpáticas del elemento intelectual de Portugal es sin duda Leal da Câmara. Leal da Câmara no es solo un artista del lápiz, el caricaturista que hizo famoso su nombre en París, en Madrid y en el mundo entero sino que también es escritor fuerte, original y hondo.

Eran fechas, como precisa Bueno, en que Leal da Câmara exponía en salas del Teatro Nacional, a pasos de donde se alojaba Darío, una colección de sus obras, muestra que acaba de ser visitada por el Presidente de la Republica.

¿Qué decir de las caricaturas, de los cuadros de Leal da Câmara? Todo el mundo los conoce: la colección de L'Assiette au beurre, de París, está llena de las muestras de ingenio de este artista, que no es portugués sino cosmopolita. Resultarían pobres cuantos elogios hiciera de los cuadros que a Da Câmara inspiraran O Baptismo y Casembour, del gran poeta Guerra Junqueiro, la vida de París, la miseria, la política y el estado actual de su país.

Solamente desconocen los públicos a Leal da Câmara, bajo esa nueva fase de su arte, el mobiliario artístico y barato. En un extremo del sillón había un armario, varis sillas, una mesa, un diván de rincón y una estantería del más modesto pionero tan original, tan artístico todo que sentíamos deseo de arrojar nuestro ajuar por la ventana, y sustituirlo por muebles "camareanos". Eran complemento de esos muebles, vasijas campesinas, cuyo valor absoluto apenas si son de unos cuantos sentimos, y cuyo valor relativo, todo colocado por la mano de Leal, era incalculable. Leal da Câmara, sin seguir la huella de William Morris, que en Inglaterra quiso generalizar el arte, quiere que aquellos que por sus escasas fuerzas 
económicas no puedan adornar sus hogares con cosas lujosas y bellas encuentren en la modestia el ornato y el confort.

"No dedico esta exposición al rico, porque ése fácilmente puede adquirir el mobiliario que le conviene - dice Leal da Câmara. Dedico estos muebles, hechos del más democrático pino, a la observación de aquéllos que tienen poco y que sienten la necesidad de crear una casa pobre, pero que corresponde a sus deseos de Arte. Cada pueblo tiene su mobiliario de arte. Las casas inglesas, las más pobres, tienen sus estantes colgados de cordones, de los cuales penden cortinas de telas decorativas, muchas veces ocultando una mala cama. Las sillas fueron ciertamente dibujadas por un artista, y en las paredes, colgadas en elegante armonía, lindas estampas de deportes, caricaturas de Hassal o de Cecil Aldin. En la casa francesa, según el temperamento de la raza, el mobiliario es de curvas sensuales, y en las paredes no es raro ver algunos grabados de los periódicos humorísticos. [...] El pobre pueblo portugués, sobre todo en las ciudades, abandonado a su desgracia secular por todas las iniciativas, y sólo considerado bueno para el trabajo y para la especulación política, no tiene una casa agradable."

Afirma Javier Bueno que Rubén Darío hizo "grandes elogios de la iniciativa del admirable artista portugués, quien nos anunció que, para el próximo año, prepara "la caricatura para la cocina" o "la química aplicada a la cocina del pueblo".

Finalizada la corta estancia de Darío en Lisboa, embarcan el "Hollandia", que "estaba fondeado en plena ría del Tajo". Fueron despedidos por muchos "amigos y admiradores" que les acompañaron hasta los últimos minutos. ¿Y el mestre Leal da Câmara? ¿Dónde estaba a las tres de la tarde, que no había acudido? ¿Se había despedido ya, debido a lo cerrado del horario del visitante, de Rubén y de Javier, poeta y periodistas amigos, durante la visita a su exposición? No. Simplemente se le había hecho muy tarde, jun montón de pequeños inconvenientes surgidos aquella mañana! Sonreirían Darío o Bueno... ¡Este entrañable Tomás, a quien le ocurren tantas cosas, siempre al filo de la puntualidad!

Leal da Câmara nunca se rendía ante sus imprevistos. Y algunos instantes antes de emprender la emprender el barco su salida de la bahía, cuenta Bueno: "vino en un bote velero, y tuvimos el gusto de estrechar por última vez la mano del gentil artista"16. ¡Cómo se iba a marchar el poeta amigo de su Lisboa sin despedir al admirado poeta! Quizás el pálpito de que podría ser la última vez.

Cuatro años después, en abril de 1916, en un nuevo viaje a Madrid, en días en que, a pocas semanas del fallecimiento de Rubén Darío, aún se rememoraba al nicaragüense como precursor de la renovación poética en lengua española, Leal da Câmara tuvo ocasión de evocar sus vivencias en el trato con el poeta, al encontrarse nuevamente con amigos de entonces. Santiago Vinardell, que lo había tratado a Leal desde el París de 1893, ahora director de La Tribuna, escribía ${ }^{17}$ :

${ }^{16}$ Una foto, de cuerpo entero, de "Leal da Câmara a bordo del Hollandia" ilustra el artículo.

${ }^{17}$ La Tribuna, Madrid, 29.03.1916. 
Fuimos muchos, en este Madrid [...], los que anduvimos por las calles acongojados y llenos de pesadumbre aquel día en que se supo la muerte de Rubén Darío, y comentaba la carta de Rafael Huidobro, desde Nicaragua, a Amado Nervo, que se había divulgado entre los amigos de la capital española, en la que se ampliaban las circunstancias de la muerte del vate entre los amigos de Rubén Darío, que en España somos legión, y para España misma, al tiempo que convocaba a todo tipo de homenajes en honor del poeta.

París consagró al artista portugués, pero aquella estancia española entre 1898 y 1900 le había servido de fuerte impulso, de autoafirmación, tras su primera salida de Portugal. Para Tomás J. Leal da Câmara, de los grandes artistas de la vanguardia del dibujo, de la caricatura, del cartel y de la decoración de interiores del siglo XX, la capital española representó un inolvidable capítulo de su desarrollo artístico. Un Madrid que lo habían constituido principalmente sus amistades, y entre ellos, Rubén Darío, uno de sus excepcionales críticos valedores, el gran poeta del Modernismo hispánico a quien supo mirar de frente y retratar con incisivo y seguro pincel.

\section{BIBLIOGRAFÍA}

DARÍO, Rubén.

2009 España contemporánea. Paris: Garnier Frères, [1901], pp. 182-192. GAVILANES, Emilio.

2009 "Vida y obra de Camilo Bargiela", en Luciérnagas, Sevilla: Renacimiento.

GonZÁlez MARTEL, J. M.

2004 "Carteles publicitarios de Leal da Câmara en la revista Mundo Gráfico de 1914", Vária Escrita. Cuadernos de Estudos Arquivísticos, Históricos e documentais, $\mathrm{n}^{\mathrm{o}} 11$, Sintra.

2005 "El testimonio fotográfico de un homenaje en abril de 1899" y "Vida y Arte, una primera revista literaria de Gómez Carrillo para el mundo hispánico", en Enrique Gómez Carrillo, cronista y director de publicaciones periódicas. Guatemala: Óscar de León Palacios, pp. 50-56 у pp. 67-104.

2009 "Leal da Câmara y Valle-Inclán: un testimonio epistolar sobre sendos lances de honor en 1899”, Madrygal:12.

2010a "El caricaturista portugués Leal da Câmara ante la crítica modernista (1898-1900)", Journal of Hispanic Modernism. Revista digital del Modernismo hispánico 1.

2010b "Pérez Galdós y Leal da Câmara. Un artista modernista portugués retrata y entrevista a don Benito en 1916", Moralia 9.

MELIM DE SOUSA, Élvio João.

2005 De Residência Privada a Casa-Museu de Leal da Câmara. Um Percurso Singular. Sintra: Edição da Câmara Municipal de Sintra. 
y CARDOSO, Luís.

2008 "Leal da Câmara Cartazista", Beira Alta, vol. LXVII. y REIS, Luciano.

2010 Textos biográficos de.... Leal da Câmara. Retrospectiva. Catálogo da Exposiçâo. Sintra: Câmara Municipal. 